\title{
FORMS OF CADMIUM IN SANDY SOILS AFTER AMENDMENT WITH SOILS OF HIGHER FIXING CAPACITY
}

\author{
S. S. Mann \& G. S. P. Ritchie
}

\begin{abstract}
Most of the Cd applied through phosphatic fertilizers in sandy soils tends to stay in mobile forms (soluble or exchangeable) and hence the risk of it leaching to underground water or its uptake by plants is higher. A sequential extraction procedure was used to assess the efficacy of amending materials (soils containing inorganic or organic adsorption components) on the re-distribution of forms of $\mathrm{Cd}$ in a sandy soil.

Amendment of the sandy soil with each of the three soils (yellow earth, lateritic podzolic and peaty sand) was generally effective in altering the more mobile or available forms of $\mathrm{Cd}$ to immobile or unavailable forms. The extent of alteration varied with the type of component present in the amendment soil, $\mathrm{pH}$ and the rate of $\mathrm{Cd}$ addition. The yellow earth was more effective at pH 7, whereas the peaty sand was equally effective at both $\mathrm{pH} 4$ and 7 in altering the mobile to immobile forms. The lateritic podzolic soil was the least effective of the soils used at any of the $\mathrm{pH}$ values.
\end{abstract}

\section{INTRODUCTION}

Cadmium (Cd) is potentially a toxic heavy metal and occurs widely in nature in small amounts. It is a common impurity in phosphorus fertilizers (Williams and David, 1973; Mann, 1989), so the Cd content of agricultural soils can increase due to the application of phosphatic fertilizers and can ultimately increase the concentration of $\mathrm{Cd}$ in the food crops grown on them.

Sandy soils cover a large area of the world and are used for agricultural production in many areas (FAOUNESCO, 1974). In Australia, such soils occupy approximately 18 million ha excluding the desert regions. Phosphorus is commonly deficient in Western Australian, sandy soils (Ozanne and Shaw, 1967) where high rates of phosphorus fertilizer are required, particularly for horticultural crops. Much of the $\mathrm{Cd}$ applied through phosphatic fertilizers to sandy soils remains in soluble or exchangeable forms due to a lack of adsorption sites on soil surfaces (Cox et al,, 1984; Mann and Ritchie, 1993). Consequently there is a greater risk of $\mathrm{Cd}$ being either taken up by crops or leached to ground water in sandy soils (Emmerich et al., 1982).

Organic matter, hydrous oxides of iron, aluminium and manganese and clay minerals are the major com- ponents of the soil that may contribute to the retention of $\mathrm{Cd}$ in non-mobile or unavailable forms (Sposito and Page, 1985; Van Riemsdijk et al., 1990). The amendment of sandy soils with material containing high amounts of these components may reduce the risk of Cd leaching or its uptake by plants (Verloo and Willaert, 1990). The application of inorganic materials such as mining wastes, e.g. bauxite residues, synthetic rutile wastes (Tacey et al., 1984; Vlahos et al., 1989) and organic wastes, e.g. sewage sludge, organic manures, etc. (Emmerich et al., 1982; Neal and Sposito, 1986) have been used to reduce the leaching of heavy metals from soils. A possible limitation with these materials is that they may themselves contain $\mathrm{Cd}$ or other heavy metals, and therefore increase the burden of $\mathrm{Cd}$ in the sandy soils and leave $\mathrm{Cd}$ in leachable and plant available forms (Soon and Bates, 1982). An alternative approach is to amend sandy soils with soils that are rich in clay, hydrous oxides or organic matter, and are free from heavy metal contamination.

Cadmium can exist in soils in several different forms depending upon the type and quantity of soil components, $\mathrm{pH}$ and the amount of $\mathrm{Cd}$ that has been applied (Christensen, 1984; Brummer, 1986; Mann and Ritchie, 1993). The incorporation into a sandy soil of soil components that can fix $\mathrm{Cd}$ could alter the equilibrium between existing forms of $\mathrm{Cd}$, and therefore reduce its solubility.

The objective of this study was to investigate the changes in the forms of $\mathrm{Cd}$ in a sandy soil after addition of soils containing inorganic or organic adsorption sites for $\mathrm{Cd}$.

\section{MATERIALS AND METHODS}

Cadmium was sequentially extracted from a siliceous sand after mixing with three soils at two $\mathrm{pH}$ values and in the presence of four rates of $\mathrm{Cd}$ addition.

\section{Soils}

The sandy soil ( $\mathrm{pH} 5.75$ ) was collected from a siliceous sand, SS (Northcote classification: Uc 2.22; Northcote, 1974). The 'amendment' soils were a yellow earth, YE (Northcote classification: Uc 1.22), a lateritic podzolic, LP (Northcote classification: Uc 5.51) and a peaty sand, PS (Northcote classification: Uc 2.33). The yellow earth $(\mathrm{pH} \mathrm{5.40)}$ and lateritic podzolic ( $\mathrm{pH} 3.74)$ soils were 
Table 1. Details of soil mixtures, some of their properties and codes used in figures

\begin{tabular}{|c|c|c|c|c|c|c|}
\hline Soils in mixture & $\mathrm{pH}$ & $\begin{array}{c}\text { Proportions } \\
(\%)\end{array}$ & $\begin{array}{l}\text { Total Cd } \\
\left(\mu \mathrm{g} \mathrm{g}^{-1}\right)\end{array}$ & $\begin{array}{c}\text { Organic } \\
\text { carbon } \\
(\%)\end{array}$ & $\begin{array}{l}\text { Main adsorption } \\
\text { components }\end{array}$ & $\begin{array}{l}\text { Codes } \\
\text { for } \\
\text { figures }\end{array}$ \\
\hline Siliceous sand & 4 & $100 / 0$ & $<0.01$ & $0 \cdot 12$ & Quartz & $1-4$ \\
\hline Siliceous sand & 7 & $100 / 0$ & $<0.01$ & $0 \cdot 12$ & & $2-7$ \\
\hline Yellow earth/siliceous sand & 4 & $50 / 50$ & 0.03 & $0 \cdot 15$ & & $3-4$ \\
\hline Yellow earth/siliceous sand & 4 & $100 / 0$ & 0.07 & $0 \cdot 31$ & Geothite and kaolinite & $5-4$ \\
\hline Yellow earth/siliceous sand & 7 & $50 / 50$ & 0.03 & 0.15 & & $4-7$ \\
\hline Yellow earth/siliceous sand & 7 & $100 / 0$ & 0.07 & 0.31 & & $6-7$ \\
\hline Lateritic podzolic/siliceous sand & 4 & $50 / 50$ & 0.06 & $0 \cdot 15$ & & $7-4$ \\
\hline Lateritic podzolic/siliceous sand & 4 & $100 / 0$ & $0 \cdot 14$ & $0 \cdot 30$ & Kaolinite & $9-4$ \\
\hline Lateritic podzolic/siliceous sand & 7 & $50 / 50$ & 0.06 & $0 \cdot 15$ & & $8-7$ \\
\hline Lateritic podzolic/siliceous sand & 7 & $100 / 0$ & $0 \cdot 14$ & $0 \cdot 30$ & & $10-7$ \\
\hline Peaty sand/siliceous sand & 4 & $50 / 50$ & $<0.01$ & 1.57 & & $11-4$ \\
\hline Peaty sand/siliceous sand & 4 & $75 / 25$ & $<0.01$ & 2.09 & & $13-4$ \\
\hline Peaty sand/siliceous sand & 4 & $100 / 0$ & $<0.01$ & $3 \cdot 14$ & Organic matter & $15-4$ \\
\hline Peaty sand/siliceous sand & 7 & $50 / 50$ & $<0.01$ & 1.57 & & $12-7$ \\
\hline Peaty sand/siliceous sand & 7 & $75 / 25$ & $<0.01$ & 2.09 & & $14-7$ \\
\hline Peaty sand/siliceous sand & 7 & $100 / 0$ & $<0.01$ & $3 \cdot 14$ & & $16-7$ \\
\hline
\end{tabular}

collected from a depth of $25-45 \mathrm{~cm}$ and were mainly dominated by goethite and kaolinite, respectively. The peaty sand ( $\mathrm{pH} 4.04)$ was collected from the $0-20 \mathrm{~cm}$ layer after removing the vegetation and clearing the debris. Organic matter was the main adsorption component of this soil. Some properties of the soils are given in Table 1.

\section{Preparation of soil mixtures}

A portion $(200 \mathrm{~g})$ of each amendment soil (yellow earth, lateritic podzolic and peaty sand), adjusted to pH 4 and 7 as described by Mann and Ritchie (1993), were taken and mixed with the siliceous sand (also adjusted to $\mathrm{pH} 4$ and 7) in different ratios to obtain sixteen soil mixtures (Table 1). The soil mixtures were brought to their field capacities by adding $\mathrm{Cd}\left(\mathrm{NO}_{3}\right)_{2}$ that contained sufficient $\mathrm{Cd}$ to amend the mixtures with $0,0.8$ and $10 \mu \mathrm{g} \mathrm{Cd} \mathrm{g}^{-1}$ soil. After thorough mixing, the soil mixtures were incubated at $40 \pm 1{ }^{\circ} \mathrm{C}$ for $24 \mathrm{~h}$, which was sufficient time for $>90 \%$ of the applied $\mathrm{Cd}$ to be adsorbed (Mann and Ritchie, 1993).

\section{Extraction of forms of Cd}

Triplicate subsamples of each mixture were extracted by a sequential extraction scheme (Mann and Ritchie, 1993) to estimate the different forms of Cd present, which will be operationally defined as soluble $(0.005 \mathrm{M}$ $\mathrm{KCl})$, exchangeable $\left(0 \cdot 1 \mathrm{M} \mathrm{BaCl}_{2}\right)$, bound to organic matter $(5.3 \% \mathrm{NaOCl})$, bound to hydrous oxides (ammonium oxalate solution, i.e. $\mathrm{AO}$ ) and residual (concentrated acids) forms of $\mathrm{Cd}$. In reality, this is an approximation because each reagent will not necessarily extract one specific form.

\section{Cadmium analysis}

Cadmium extracted by different solutions was analysed by atomic absorption spectroscopy using either a flameAAS or a graphite furnace (Mann and Ritchie, 1993). The accuracy of the methods for analysing $\mathrm{Cd}$ in different solutions was tested by Mann (1993).

\section{Data analysis}

Standard errors of the triplicate samples were calculated and are shown as error bars in all figures.

\section{RESULTS}

\section{Native Cd}

No $\mathrm{Cd}$ was extracted from the siliceous sand or the mixtures containing the peaty sand $\left(<10 \mathrm{ng} \mathrm{g}^{-1}\right.$ soil) at either $\mathrm{pH}$ value in any of the extracting solutions. All of the native $\mathrm{Cd}$ was extracted as residual $\mathrm{Cd}$ from the mixtures of the yellow earth and the lateritic podzolic soils at $\mathrm{pH} 4$ and 7 (data not shown).

\section{Added Cd}

The addition of the amendment soils had a marked effect on the forms of added Cd in the siliceous sand, when $\mathrm{Cd}$ was applied at different rates, and the effect varied with $\mathrm{pH}$. The amount of $\mathrm{Cd}$ and the percentage of applied $\mathrm{Cd}$ in each form varied with the treatments in a similar manner.

\section{Siliceous sand (100\%)}

In the $100 \%$ siliceous sand, the added $\mathrm{Cd}$ was almost wholly recovered in the forms of either $\mathrm{Cd}-\mathrm{KCl}$ (soluble) or Cd- $\mathrm{BaCl}_{2}$ (exchangeable). The highest recoveries of added $\mathrm{Cd}$, as $\mathrm{Cd}-\mathrm{NaOCl}$ (bound to organic matter) and in Cd-acid extractable (residual forms) were 5 and $4 \%$ respectively at $\mathrm{pH} 7$ and $10 \mu \mathrm{g} \mathrm{g}^{-1} \mathrm{Cd}$ added. At $\mathrm{pH} 4$, the recoveries in these fractions were $<2 \%$ at all the $\mathrm{Cd}$ application rates. The recovery of added $\mathrm{Cd}$ in Cd-AO (bound to oxide) was $<1 \%$.

The $\mathrm{pH}$ of the sand and the rate of $\mathrm{Cd}$ addition had a large influence on the relative proportions of $\mathrm{Cd}-\mathrm{KCl}$ and $\mathrm{Cd}-\mathrm{BaCl}_{2}$. At $\mathrm{pH} \mathrm{4}$, at either $\mathrm{Cd}$ addition rate, $60-70 \%$ of added $\mathrm{Cd}$ was in the $\mathrm{Cd}-\mathrm{KCl}$ form, the rest being nearly all as $\mathrm{Cd}-\mathrm{BaCl}_{2}$. At $\mathrm{pH} 7$ and with $0.8 \mu \mathrm{g} \mathrm{g}^{-1}$ added $\mathrm{Cd}, 40 \%$ was present as $\mathrm{Cd}-\mathrm{KCl}$ and $60 \%$ as $\mathrm{Cd}-\mathrm{BaCl}_{2}$; for the $10 \mu \mathrm{g} \mathrm{g}^{-1} \mathrm{Cd}$ rate, the respective proportions were 15 and $80 \%$. 


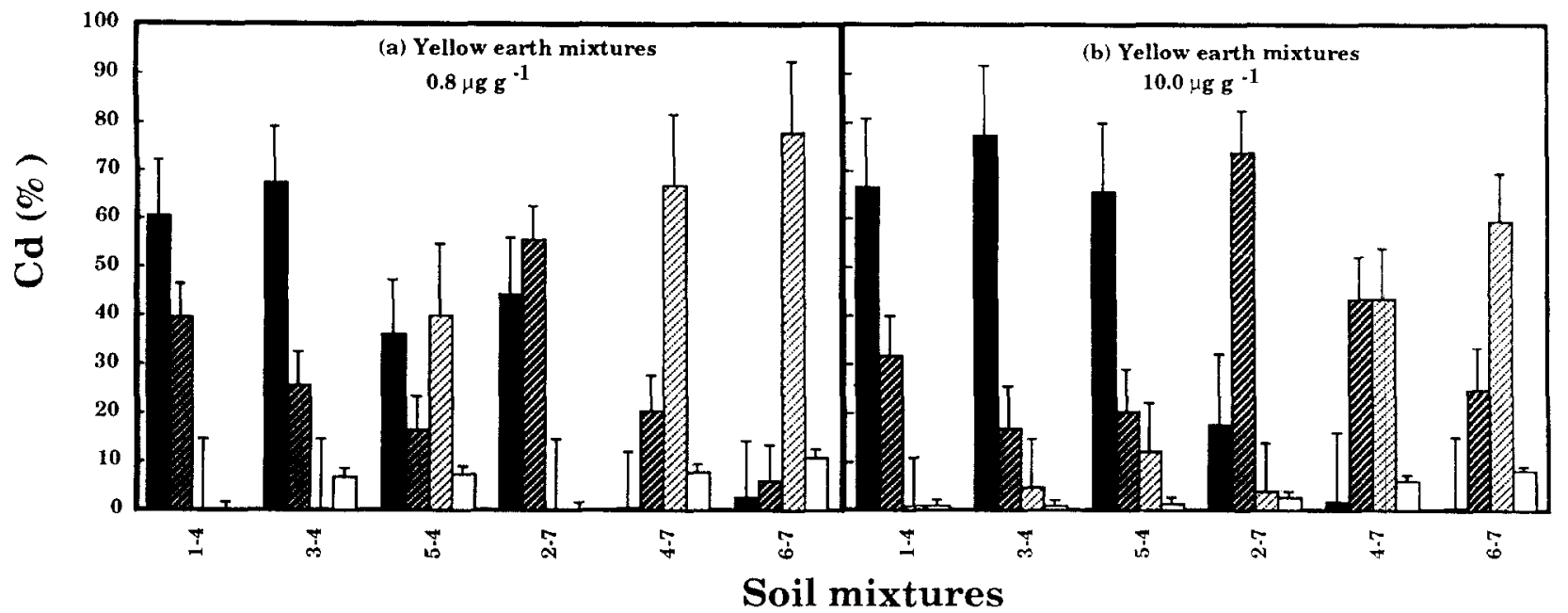

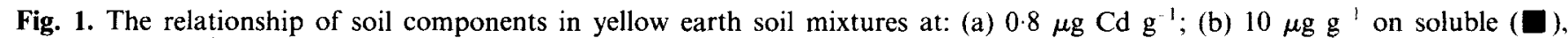
exchangeable $(\square)$, Cd bound to oxides $(\square)$ and residual $\mathrm{Cd}(\square)$ after mixing with siliceous sand. Vertical bar denotes the standard errors.

\section{Yellow earth soil mixtures}

At both application rates of $\mathrm{Cd}$ and at $\mathrm{pH} 4$, there was no difference between the $\% \mathrm{Cd}-\mathrm{KCl}$ in the $50 \%$ yellow earth mixture and the siliceous sand (Figs 1(a) and 1(b)). At $\mathrm{pH} \mathrm{7,} \mathrm{a} \mathrm{large} \mathrm{decrease} \mathrm{in} \mathrm{Cd}-\mathrm{KCl}(20-40 \%)$ was noticed. The extent of the decrease was less at the higher Cd application rate (Figs 1(a) and 1(b)).

The percentage of $\mathrm{Cd}$ found in each extract was compared with that predicted by the equation $\left(x Z_{1}+\right.$ $\left.y Z_{2}\right) 10^{-2}$. Respectively, $x$ and $y$ were the percentage $\mathrm{Cd}$ found in the siliceous sand and in each component separately, and $Z_{1}$ and $Z_{2}$ were the respective proportions in which the siliceous sand and a component were mixed. The equation estimates the percentage $\mathrm{Cd}$ that would be found in each extract if no redistribution of $\mathrm{Cd}$ forms had occurred. The $\mathrm{Cd}-\mathrm{KCl}$ in the $50 \%$ mixture was greater than the predicted value at $\mathrm{pH} 4$ and less at $\mathrm{pH} 7$ (Table 2).

The $\mathrm{Cd}-\mathrm{BaCl}_{2}$ decreased with increase in the yellow earth in a mixture at all the $\mathrm{Cd}$ rates and at both $\mathrm{pH}$ values (Figs 1(a) and 1(b)). The extent of the decrease in $\mathrm{Cd}-\mathrm{BaCl}_{2}$ declined with increasing $\mathrm{Cd}$ addition at both the $\mathrm{pH}$ values. At $\mathrm{pH} 4$, the $\mathrm{Cd}-\mathrm{BaCl}_{2}$ decreased by almost $15 \%$ at both rates of $\mathrm{Cd}$ application when the mixture contained 50\% yellow earth; at $\mathrm{pH} 7$ the decrease was $>35 \%$ (Figs 1 (a) and 1 (b)). The $\mathrm{Cd}-\mathrm{BaCl}_{2}$ at both the $\mathrm{pH}$ values in the $50 \%$ mixtures was less than the predicted amount at all the rates of $\mathrm{Cd}$ application (Table 2).

The $\mathrm{NaOCl}$ solution did not extract $\mathrm{Cd}$ from any of the mixtures at $\mathrm{pH} 4$ at any of the rates of $\mathrm{Cd}$ application. At $\mathrm{pH} 7$, this fraction was very small $(<5 \%)$; a slight increase occurred as the amount of yellow earth in a mixture increased and as the rate of $\mathrm{Cd}$ addition increased (data not shown).

The Cd-AO increased with an increase in the yellow earth in a mixture at both $\mathrm{pH}$ values and at all the rates of $\mathrm{Cd}$ addition (Figs 1(a) and 1(b)). The relative increase in $\mathrm{Cd}-\mathrm{AO}$ lessened with the rate of $\mathrm{Cd}$ addition at both $\mathrm{pH}$ values (Figs 1(a) and 1(b)). At $\mathrm{pH} 7$, the amount of $\mathrm{Cd}-\mathrm{AO}$ was almost nil in the $0 \%$ yellow earth mixture, and increased to nearly 70 and $45 \%$ in

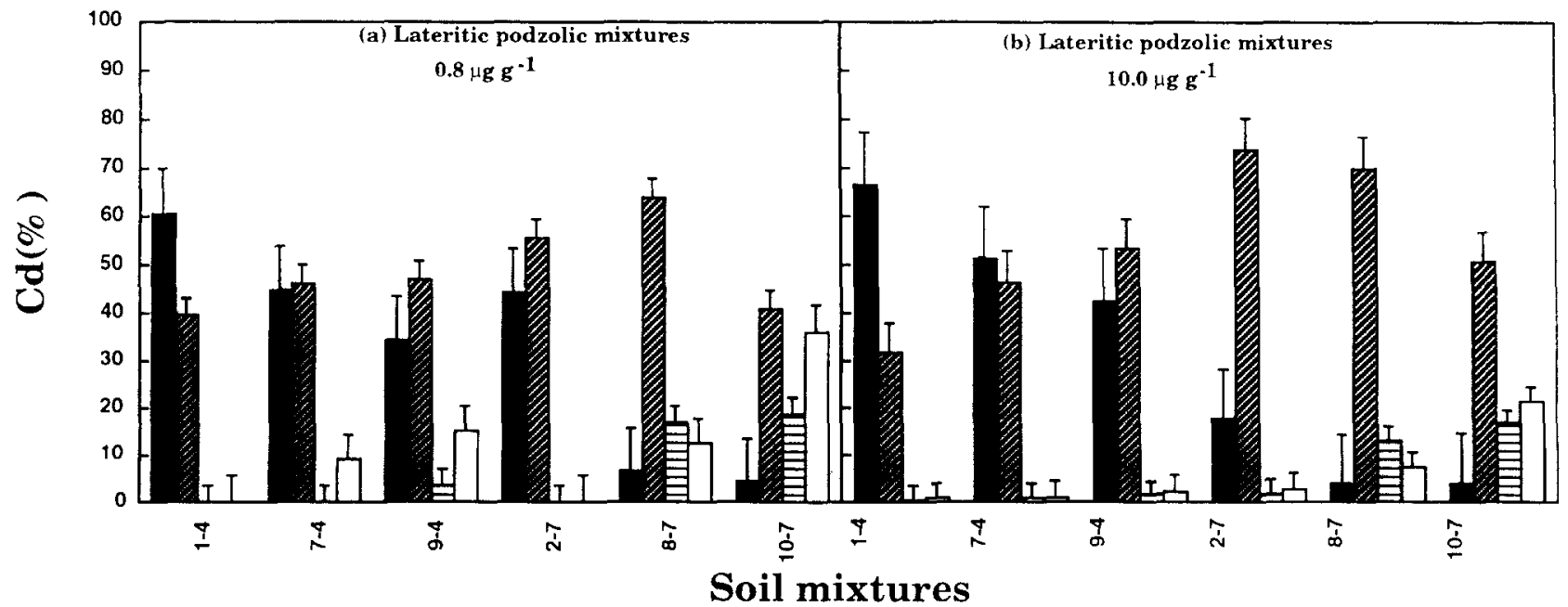

Fig. 2. The relationship of soil components in lateritic podzolic soil mixtures at: (a) $0.8 \mu \mathrm{g} \mathrm{Cd}^{-1}$; (b) $10 \mu \mathrm{g} \mathrm{g}^{-1}$ on soluble ( $\mathbf{Q}$ ), exchangeable $(\square)$, Cd bound to organic matter $(\boxminus)$ and residual $C d(\square)$ after mixing with siliceous sand. Vertical bar denotes the standard errors. 
Table 2. Cd (\%) found and predicted in different soil mixtures

\begin{tabular}{|c|c|c|c|c|c|c|c|c|c|c|c|c|}
\hline \multirow[t]{2}{*}{$\begin{array}{l}\text { Mixture } \\
(\%)\end{array}$} & \multirow[t]{2}{*}{$\mathrm{pH}$} & \multirow[t]{2}{*}{$\begin{array}{l}\text { Cd addition } \\
\left(\mu \mathrm{g} \mathrm{g}^{-1}\right)\end{array}$} & \multicolumn{2}{|c|}{$\begin{array}{c}\mathrm{Cd}-\mathrm{KCl} \\
(\%)\end{array}$} & \multicolumn{2}{|c|}{$\begin{array}{c}\mathrm{Cd}-\mathrm{BaCl}_{2} \\
(\%)\end{array}$} & \multicolumn{2}{|c|}{$\begin{array}{c}\mathrm{Cd}-\mathrm{NaOCl} \\
(\%)\end{array}$} & \multicolumn{2}{|c|}{$\underset{(\%)}{C d-a m m} . O x$} & \multicolumn{2}{|c|}{$\begin{array}{c}\text { Cd-residual } \\
(\%)\end{array}$} \\
\hline & & & Found & Predicted & Found & Predicted & Found & Predicted & Found & Predicted & Found & Predicted \\
\hline $\begin{array}{l}\text { Yellow earth } \\
\qquad(50 \%)\end{array}$ & $\begin{array}{l}4 \\
7\end{array}$ & $\begin{array}{c}0.8 \\
10 \\
0 \cdot 8 \\
10\end{array}$ & $\begin{array}{r}67.5 \\
77 \cdot 2 \\
0.6 \\
1.7\end{array}$ & $\begin{array}{l}48 \cdot 3 \\
65 \cdot 4 \\
24 \cdot 0 \\
10 \cdot 2\end{array}$ & $\begin{array}{l}25 \cdot 5 \\
17 \cdot 1 \\
20 \cdot 6 \\
43 \cdot 7\end{array}$ & $\begin{array}{l}27 \cdot 9 \\
26 \cdot 0 \\
30 \cdot 9 \\
49 \cdot 3\end{array}$ & $\begin{array}{r}<0 \cdot 1 \\
0 \cdot 3 \\
4 \cdot 0 \\
5 \cdot 0\end{array}$ & $\begin{array}{r}<0.1 \\
0.5 \\
1.1 \\
4.5\end{array}$ & $\begin{array}{r}<0.1 \\
4.6 \\
67.0 \\
43.7\end{array}$ & $\begin{array}{r}20.0 \\
6.5 \\
39.0 \\
31.6\end{array}$ & $\begin{array}{l}7 \cdot 0 \\
0 \cdot 8 \\
7 \cdot 8 \\
6 \cdot 0\end{array}$ & $\begin{array}{l}3.7 \\
1 \cdot 1 \\
5 \cdot 3 \\
5.4\end{array}$ \\
\hline $\begin{array}{l}\text { Lateritic Podzolic } \\
\quad(50 \%)\end{array}$ & $\begin{array}{l}4 \\
7\end{array}$ & $\begin{array}{c}0.8 \\
10 \\
0.8 \\
10\end{array}$ & $\begin{array}{r}44.6 \\
51.5 \\
6.7 \\
3.8\end{array}$ & $\begin{array}{l}47 \cdot 5 \\
54 \cdot 6 \\
24.4 \\
10 \cdot 7\end{array}$ & $\begin{array}{l}46 \cdot 3 \\
46 \cdot 6 \\
64 \cdot 1 \\
70 \cdot 0\end{array}$ & $\begin{array}{l}43 \cdot 3 \\
42 \cdot 4 \\
48 \cdot 2 \\
62 \cdot 3\end{array}$ & $\begin{array}{r}<0.1 \\
0.9 \\
16 \cdot 8 \\
13.2\end{array}$ & $\begin{array}{l}1.8 \\
0.9 \\
9.3 \\
9.3\end{array}$ & $\begin{array}{r}<0.1 \\
<0.1 \\
<0.1 \\
5.6\end{array}$ & $\begin{array}{r}<0.1 \\
0.4 \\
<0.1 \\
5.6\end{array}$ & $\begin{array}{r}9.1 \\
1.0 \\
12.5 \\
7 \cdot 4\end{array}$ & $\begin{array}{r}7.5 \\
1.6 \\
18.1 \\
12.0\end{array}$ \\
\hline $\begin{array}{l}\text { Peaty sand } \\
\qquad(50 \%)\end{array}$ & $\begin{array}{l}4 \\
7\end{array}$ & $\begin{array}{c}0 \cdot 8 \\
10 \\
0 \cdot 8 \\
10\end{array}$ & $\begin{array}{r}10 \cdot 1 \\
9 \cdot 6 \\
30 \cdot 9 \\
22 \cdot 1\end{array}$ & $\begin{array}{l}30.8 \\
33.8 \\
27.2 \\
17.5\end{array}$ & $\begin{array}{l}51.0 \\
53.9 \\
22 \cdot 1 \\
15.9\end{array}$ & $\begin{array}{l}56 \cdot 3 \\
50 \cdot 8 \\
35 \cdot 1 \\
45 \cdot 5\end{array}$ & $\begin{array}{l}36.5 \\
31.2 \\
41.6 \\
54.5\end{array}$ & $\begin{array}{l}13 \cdot 0 \\
12 \cdot 2 \\
35 \cdot 3 \\
29 \cdot 8\end{array}$ & $\begin{array}{l}2 \cdot 5 \\
4 \cdot 8 \\
5 \cdot 4 \\
6 \cdot 4\end{array}$ & $\begin{array}{r}<0 \cdot 1 \\
2 \cdot 4 \\
2 \cdot 4 \\
5 \cdot 3\end{array}$ & $\begin{array}{r}<0.1 \\
0.4 \\
<0.1 \\
0.9\end{array}$ & $\begin{array}{r}<0.1 \\
0.8 \\
<0.1 \\
1.9\end{array}$ \\
\hline $\begin{array}{l}\text { Peaty sand } \\
\quad(75 \%)\end{array}$ & $\begin{array}{l}4 \\
7\end{array}$ & $\begin{array}{c}0 \cdot 8 \\
10 \\
0 \cdot 8 \\
10\end{array}$ & $\begin{array}{r}3 \cdot 4 \\
2 \cdot 0 \\
23 \cdot 0 \\
19 \cdot 1\end{array}$ & $\begin{array}{l}15.9 \\
17.5 \\
18.6 \\
17.4\end{array}$ & $\begin{array}{l}61 \cdot 1 \\
62 \cdot 6 \\
10 \cdot 0 \\
10 \cdot 3\end{array}$ & $\begin{array}{l}64.7 \\
60.5 \\
24.9 \\
31.4\end{array}$ & $\begin{array}{l}33 \cdot 0 \\
30 \cdot 1 \\
58 \cdot 8 \\
62 \cdot 4\end{array}$ & $\begin{array}{l}19.4 \\
18 \cdot 1 \\
52.9 \\
43.8\end{array}$ & $\begin{array}{l}2 \cdot 5 \\
4 \cdot 7 \\
7 \cdot 0 \\
6 \cdot 7\end{array}$ & $\begin{array}{r}<0 \cdot 1 \\
3 \cdot 2 \\
3 \cdot 5 \\
6 \cdot 0\end{array}$ & $\begin{array}{r}<0.1 \\
0.6 \\
1.2 \\
1.5\end{array}$ & $\begin{array}{r}<0.1 \\
0.8 \\
<0.1 \\
1.5\end{array}$ \\
\hline
\end{tabular}




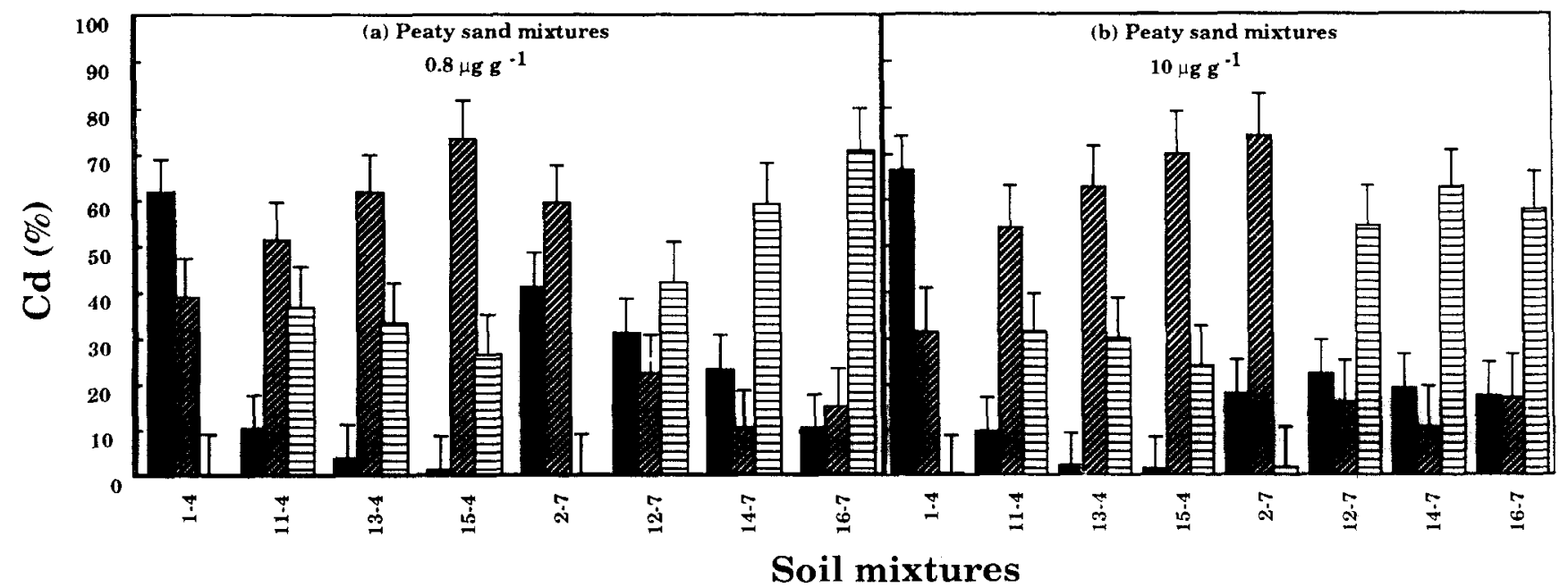

Fig. 3. The relationship of soil components in peaty sand soil mixtures at: (a) $0.8 \mu \mathrm{g} \mathrm{Cd} \mathrm{g}^{-1}$; (b) $10 \mu \mathrm{g} \mathrm{g}^{-1}$ on soluble ( $\square$ ), exchangeable $(\square)$ and $\mathrm{Cd}$ bound to organic matter $(\mathrm{G})$ after mixing with siliceous sand. Vertical bar denotes the standard errors.

the $50 \%$ yellow earth mixtures at 0.8 and $10 \mu \mathrm{g} \mathrm{g}^{-1} \mathrm{Cd}$ application rates respectively (Figs 1 (a) and 1(b)). In contrast, at $\mathrm{pH} 4$ there was no change in the amount of $\mathrm{Cd}-\mathrm{AO}$ when the yellow earth content increased to $50 \%$ in the mixture. The $\mathrm{Cd}-\mathrm{AO}$ at $\mathrm{pH} 4$ was less than the predicted value in the $50 \%$ mixture, whereas at $\mathrm{pH} 7$ the $\mathrm{Cd}-\mathrm{AO}$ was more than the predicted value (Table 2).

Acid extractable $\mathrm{Cd}$ at both $\mathrm{pH}$ values was a small fraction $(<10 \%)$ of the total $\mathrm{Cd}$ applied to all the soil mixtures at all the rates of $\mathrm{Cd}$ application (Figs 1(a) and 1(b)). A slight increase in Cd-acid extractable was observed with an increase in yellow earth in a mixture at both $\mathrm{pH}$ values. The increase was greatest at $\mathrm{pH} 7$ and with the higher rate of $\mathrm{Cd}$ addition (Figs $\mathrm{l}(\mathrm{a})$ and 1(b)). The Cd-acid extractable differed slightly from that predicted in the $50 \%$ mixtures at both $\mathrm{pH}$ values (Table 2).

\section{Lateritic podzolic soil mixtures}

At both $\mathrm{pH}$ values and at all the rates of $\mathrm{Cd}$ addition, the $\mathrm{Cd}-\mathrm{KCl}$ tended to be lower in the $50 \%$ mixture than in the siliceous sand (Figs 2(a) and 2(b)). The decrease in $\% \mathrm{Cd}-\mathrm{KCl}$ was greater at $\mathrm{pH} 7$ than at $\mathrm{pH} \mathrm{4}$, and smaller at the higher rate of $\mathrm{Cd}$ addition. At $\mathrm{pH} 7$ and $0.8 \mu \mathrm{g} \mathrm{g}^{-1} \mathrm{Cd}$ addition, the decrease in $\mathrm{Cd}-\mathrm{KCl}$ was almost $40 \%$, whereas at $\mathrm{pH} 4$ the decrease was approximately $15 \%$ (Fig. 2(a)). The Cd-KCl in the $50 \%$ mixture at $\mathrm{pH} 4$ was very similar to that predicted; at $\mathrm{pH} 7$ it was less than the predicted value at all the rates of Cd application (Table 2).

The $\mathrm{Cd}-\mathrm{BaCl}_{2}$ was $30-80 \%$ of the added $\mathrm{Cd}$ at both $\mathrm{pH}$ values and at all the rates of $\mathrm{Cd}$ addition (Figs 2(a) and $2(\mathrm{~b})$ ). At $\mathrm{pH} 4$, mixing $50 \%$ of the lateritic podzolic soil with the siliceous sand slightly increased the $\mathrm{Cd}$ $\mathrm{BaCl}_{2}$ at all the rates of $\mathrm{Cd}$ addition. At $\mathrm{pH} 7$, the Cd$\mathrm{BaCl}_{2}$ increased slightly at $0.8 \mu \mathrm{g} \mathrm{g}^{-1}$ and decreased slightly at $10 \mu \mathrm{g} \mathrm{g}^{-1} \mathrm{Cd}$ addition (Figs 2(a) and 2(b)). The $\mathrm{Cd}-\mathrm{BaCl}_{2}$ found in the $50 \%$ mixture was slightly higher than predicted at both $\mathrm{pH}$ values; however at $\mathrm{pH} \mathrm{7,} \mathrm{the} \mathrm{difference} \mathrm{in} \mathrm{the} \mathrm{amounts} \mathrm{found} \mathrm{and} \mathrm{that}$ predicted was greater $(8-16 \%)$ in comparison to the difference at $\mathrm{pH} 4$, i.e. $<5 \%$ (Table 2 ).

At $\mathrm{pH} \mathrm{4}$, the $\mathrm{Cd}-\mathrm{NaOCl}$ was a negligible fraction $(<5 \%)$ in all the soil mixtures at all the rates of $\mathrm{Cd}$ addition (Figs 2(a) and 2(b)). At pH 7, the $\mathrm{Cd}-\mathrm{NaOCl}$ slightly increased $(15-20 \%)$ when the siliceous sand was mixed with $50 \%$ of the lateritic podzolic soil irrespective of the rate of Cd application (Figs 2(a) and 2(b)). The $\mathrm{Cd}-\mathrm{NaOCl}$ found at $\mathrm{pH} 7$ was more than predicted in the $50 \%$ mixture (Table 2).

The Cd-AO was almost a negligible fraction at $\mathrm{pH} 4$ $(<2 \%)$ and was very small $(\approx 5 \%)$ at $\mathrm{pH} 7$ in the $50: 50$ mixtures at all the rates of $\mathrm{Cd}$ application (data not shown).

At both $\mathrm{pH}$ values and at all the rates of $\mathrm{Cd}$ addition, the Cd-acid extractable increased when the lateritic podzolic soil was mixed with the siliceous sand (Figs 2(a) and 2(b)). The extent of the increase at both $\mathrm{pH}$ values declined with the rate of $\mathrm{Cd}$ addition (Figs 2(a) and 2(b)). The Cd-acid extractable found in the $50 \%$ mixture and that which was predicted were similar at $\mathrm{pH} \mathrm{4}$, whereas at $\mathrm{pH} 7$ it was slightly less than predicted (Table 2).

\section{Peaty sand soil mixtures}

The $\mathrm{Cd}-\mathrm{KCl}$ decreased markedly with an increase in the peaty sand content in the soil mixture at both $\mathrm{pH}$ values, except at $\mathrm{pH} 7$ when $\mathrm{Cd}$ was applied at a rate of $10 \mu \mathrm{g} \mathrm{g}^{-1}$ (Figs 3(a) and 2(b)). At pH 4, the Cd-KCl was $60 \%$ in mixtures containing no peaty sand and decreased to approximately $10 \%$ when the amount of peaty sand in the mixture increased to $50 \%$ and was $<5 \%$ in the mixture containing $75 \%$ peaty sand (Figs 3 (a) and $3(b))$. At $\mathrm{pH} 7$, the $\mathrm{Cd}-\mathrm{KCl}$ decreased slightly $(\approx 10 \%)$ at the lower rate of $\mathrm{Cd}$ application $\left(0.8 \mu \mathrm{g} \mathrm{g}^{-1}\right)$, but at the higher rate $\left(10 \mu \mathrm{g} \mathrm{g}^{-1}\right)$ of $\mathrm{Cd}$ addition there was no change when the peaty sand increased from 0 to $50 \%$ in the soil mixture. At $\mathrm{pH} \mathrm{4}$, the $\mathrm{Cd}-\mathrm{KCl}$ found in the 50 and $75 \%$ mixtures was less than that predicted at both rates of $\mathrm{Cd}$ application, whereas at $\mathrm{pH} 7$ the amounts found and those predicted were similar (Table 2). 
The $\mathrm{Cd}-\mathrm{BaCl}_{2}$ increased linearly at $\mathrm{pH} 4$ with increasing percentage of peaty sand in a mixture at all the rates of $\mathrm{Cd}$ application, whereas at $\mathrm{pH} 7$ this fraction decreased with increasing peaty sand content in the soil mixture (Fig 3(a) and 3(b)). At pH 7, the maximum decrease in $\mathrm{Cd}-\mathrm{BaCl}_{2}$ was observed when the peaty sand in the mixture increased from 0 to $50 \%$ at all rates of $\mathrm{Cd}$ application. At $\mathrm{pH} 4$, the $\mathrm{Cd}-\mathrm{BaCl}_{2}$ found in the 50 and $75 \%$ mixtures was almost the same as predicted, whereas at $\mathrm{pH} 7$ it was less than predicted in the mixtures at all rates of $\mathrm{Cd}$ application (Table 2).

The $\mathrm{Cd}-\mathrm{NaOCl}$ tended to increase with increasing percentage of peaty sand in a mixture at $\mathrm{pH} 7$ at all rates of $\mathrm{Cd}$ addition (Figs 3(a) and 3(b)). At $\mathrm{pH} \mathrm{4,} \mathrm{this}$ fraction increased from 0 to $>30 \%$ when the peaty sand in a mixture increased from 0 to $50 \%$. However, no further increase was observed with additional peaty sand in the soil mixture. In contrast, at $\mathrm{pH} \mathrm{7,} \mathrm{the} \mathrm{Cd-}$ $\mathrm{NaOCl}$ increased from 0 to $>40 \%$ with the addition of $50 \%$ peaty sand, and there was a further increase when the peaty sand in the mixture increased to $75 \%$ (Figs 3(a) and 3(b)). The extent of the increase was less at the higher rate of $\mathrm{Cd}$ addition. The $\mathrm{Cd}-\mathrm{NaOCl}$ found in the 50 and $75 \%$ mixtures was more than predicted at both $\mathrm{pH}$ values and at all rates of $\mathrm{Cd}$ addition (Table 2).

The $\mathrm{Cd}$ in the ammonium oxalate and the acid extracts was a very minor fraction $(<7 \%)$ in all the peaty sand mixtures at both $\mathrm{pH}$ values (data not shown).

\section{DISCUSSION}

Amendment of the siliceous sand with each of the three soils was generally effective in changing the mobile or available forms of $\mathrm{Cd}$ to immobile or unavailable forms. The extent of transformation varied with the type of adsorption component present in the amendment soil, $\mathrm{pH}$ and the rate of $\mathrm{Cd}$ application. Soluble and exchangeable forms of $\mathrm{Cd}$ (considered the most labile or available forms for leaching and plant uptake; Harrison et al., 1981; Soon and Bates, 1982; Hickey and Kittrick, 1984) decreased in the soil mixtures, whereas $\mathrm{Cd}$ bound by organic matter and hydrous oxides (less-labile or less available forms) increased when the siliceous sand was amended with the yellow earth, lateritic podzolic or peaty sand.

The yellow earth and peaty sand were generally more effective than the lateritic podzolic soil. The effects of $\mathrm{pH}$ and rate of $\mathrm{Cd}$ addition in transforming $\mathrm{Cd}$ were greater in the yellow earth mixtures than when the peaty sand was used. The lateritic podzolic soil was not as effective in amending material as the other two soils at either of the $\mathrm{pH}$ values.

The extent to which leaching or uptake were reduced by the amendment soils could not be predicted directly from the equation used for estimating the amount of $\mathrm{Cd}$ found in each form. Each soil could be considered effective at amending the siliceous sand if (i) the amounts of $\mathrm{Cd}$ found in soluble plus exchangeable form was less than the predicted value and (ii) the amounts of $\mathrm{Cd}$ bound to organic matter, hydrous oxides or in the residual form were greater than the corresponding predicted values for each of those forms. For example, without the amendment, $>95 \%$ of the $\mathrm{Cd}$ in the siliceous sand was present in mobile or available forms. When the siliceous sand was amended with the yellow earth, the soluble form of $\mathrm{Cd}$ at $\mathrm{pH} 4$ was greater than predicted (Table 2), presumably because of a lack of sites. At pH 7, the actual amount of soluble $\mathrm{Cd}$ was less than the predicted value, whereas $\mathrm{Cd}$ bound to oxides was more than the predicted value, suggesting that enough adsorption sites were present to transform the soluble $\mathrm{Cd}$ originating from the siliceous sand (Table 2). The extent of the transformation at $\mathrm{pH} 7$ depended upon the rate of $\mathrm{Cd}$ application. At $0.8 \mu \mathrm{g} \mathrm{g}^{-1}$ of $\mathrm{Cd}$ addition, more than $70 \%$ of the $\mathrm{Cd}$ was retained in immobile or unavailable forms, in comparison to $45 \%$ at $10 \mu \mathrm{g} \mathrm{g}^{-1}$.

The addition of the peaty sand to the siliceous sand, to achieve a $50 \%$ peaty sand mixture at $\mathrm{pH} 4$, resulted in smaller amounts of soluble $\mathrm{Cd}$ than predicted and larger amounts bound to organic matter than predicted (Table 2). In this instance, there were sufficient sites for nearly $30-35 \%$ of the soluble $\mathrm{Cd}$ to be transformed to $\mathrm{Cd}$ bound by organic matter (Figs 3(a) and 3(b)). At $\mathrm{pH} 7,40-55 \%$ of the $\mathrm{Cd}$ was transformed to immobile forms. However, at $\mathrm{pH} \mathrm{7,} \mathrm{the} \mathrm{soluble} \mathrm{Cd}$ was slightly greater than predicted and represented as much as $20-30 \%$ of the added $\mathrm{Cd}$. The increase in soluble form of $\mathrm{Cd}$ can possibly be attributed to the dissolution of organic matter at higher $\mathrm{pH}$ values thereby releasing Cd into the soil solution (Kuo and Baker, 1980).

When the siliceous sand was amended with the lateritic podzolic soil, most of the Cd determined and that predicted in each of the forms were more or less similar at $\mathrm{pH} 4$. At $\mathrm{pH} 7$, the soluble $\mathrm{Cd}$ was less than that predicted and the exchangeable $\mathrm{Cd}$ was slightly greater than that predicted (Table 2). It appears that the majority of soluble $\mathrm{Cd}$ transformed into exchangeable forms at higher pH values (Figs 2(a) and 2(b)). These changes would not significantly affect the leachability or availability of Cd. However, a slight increase in $\mathrm{Cd}$ bound to organic matter and that in the residual fraction at $\mathrm{pH} 7$ was observed which could be attributed to an increase in the number of adsorption sites due to the development of $\mathrm{pH}$ dependent adsorption sites on organic matter and on the edges of kaolinite (Bolland et al., 1976; Lim et al., 1980).

The results obtained in this work suggest that the amendment of sandy soils to reduce the potential of $\mathrm{Cd}$ leaching or uptake by plants may be achieved by the addition of yellow earth (i.e. materials containing hydrous oxides) at neutral $\mathrm{pH}$ values or peaty sand (i.e. materials containing organic matter) at low $\mathrm{pH}$ values. However, the use of yellow earth at neutral $\mathrm{pH}$ values could cause the leaching of phosphorus because the soil's ability to retain phosphorus (being an anion) would be reduced (Barrow, 1982). To reduce the risk of phosphorus leaching when using an amendment 
containing hydrous oxides at $\mathrm{pH} 7$, it would be advisable to use a less soluble source of $\mathbf{P}$ (Weaver et al., 1988) or smaller amounts of $P$ fertilizer. A smaller application of fertilizer would mean smaller additions of $\mathrm{Cd}$ and ultimately more transformation of mobile forms to immobile forms as discussed earlier (i.e. $70 \%$ at $0.8 \mu \mathrm{g} \mathrm{g}^{-1}$ versus $45 \%$ at $10 \mu \mathrm{g} \mathrm{g}^{-1}$ ). Increasing the $\mathrm{pH}$ of a mixture would be an additional cost if the yellow earth had to be used for amending a sandy soil with a $\mathrm{pH}<5.5$.

The addition of organic matter, such as in peaty sand, appears to be an effective amending material for the acidic sandy soils examined in this work. Decreases in $\mathrm{Cd}$ availability under acidic conditions in the presence of organic matter have been reported previously (Tyler and McBride. 1982; Elliott et al., 1986; Tiller, 1988). In another study conducted in New Zealand, the removal of organic matter from one of the soils reduces $\mathrm{Cd}$ adsorption by $50 \%$ (Kim and Fergusson, 1992). At neutral $\mathrm{pH}$ values there may be some dissolution of the organic matter resulting in a reduced effectiveness for $\mathrm{Cd}$ retention (Mann and Ritchie, 1993). Nevertheless this appears to be relatively small in relation to the proportion of added $\mathrm{Cd}$ transformed from plant available to unavailable forms.

\section{CONCLUSIONS}

The problem of $\mathrm{Cd}$ leaching or its availability to plants in sandy soils can be reduced by amending sandy soils with soils containing high amounts of hydrous oxides or organic matter.

A yellow earth (containing goethite) was the most effective at $\mathrm{pH} 7$ in transforming mobile forms of $\mathrm{Cd}$ to immobile forms, whereas a peaty sand (containing organic matter) was more effective at $\mathrm{pH} 4$. A lateritic podzolic soil (containing kaolinite) was partially effective at high $\mathrm{pH}$ values, but its ability to transform mobile forms to immobile forms was comparatively much less than the other two soils.

\section{REFERENCES}

Barrow, N. J. (1982). Possibility of using caustic residue from bauxite for improving the chemical and physical properties of sandy soils. Aust. J. Agric. Res., 33, 275-85.

Bolland, M. D. A., Posner, A. M. \& Quirk, J. P. (1976). Surface charge on kaolinites in aqueous suspension. Aust. $J$. Soil Res., 14, 197-216.

Brummer, G. W. (1986). Heavy metal species, mobility and availability in soils. In The Importance of Chemical "Speciation" in Environmental Processes, ed. M. Bernhard, F. E. Brinckman \& P. J. Sadlers. Springer-Verlag, Berlin. pp. 169-92.

Christensen, T. H. (1984). Cadmium soil sorption at low concentrations: II Reversibility effect of changes in solute composition, and effect of soil aging. Water Air Soil Pollut., 21, $105-14$.

Cox, J. A., Slonawska, K., Gatchel, D. K. \& Hiebert, A. B. (1984). Metal speciation by Donnan dialysis. Anal. Chem. 56, 650-3

Elliott, H. A., Liberati, M. R. \& Huang, C. P. (1986). Competitive adsorption of heavy metals by soils. J. Environ. Qual., 15, 214-19.
Emmerich, W. E., Lund, L. J., Page, A. L. \& Chang, A. C. (1982). Movement of heavy metals in sewage sludge-treated soils. J. Environ. Qual., 11, 174-8.

FAO-UNESCO (1974). Soil map of the world. 1:5,000,000. Food and Agriculture Organization-United Nations Educational, Scientific and Cultural Organization, Paris.

Harrison, R. M., Laxe, D. P. H. \& Wilson, S. J. (1981). Chemical associations of $\mathrm{Pb}, \mathrm{Cd}, \mathrm{Cu}$ and $\mathrm{Zn}$ in street dusts and roadside soils. Environ. Sci. Technol., 15, 1378 83.

Hickey, M. G. \& Kittrick, J. A. (1984). Chemical partitioning of $\mathrm{Cd}, \mathrm{Ni}$ and $\mathrm{Zn}$ in soils and sediments containing high levels of heavy metals. J. Environ. Qual., 13, 189-97.

Kim, N. D. \& Fergusson, J. E. (1992). Adsorption of cadmium by an aquent New Zealand soil and its components. Aust. J. Soil Res., 30, 159-67.

Kuo, S. \& Baker, A. S. (1980). Sorption of $\mathrm{Cu}, \mathrm{Zn}$ and $\mathrm{Cd}$ by some acid soil. Soil Sci. Soc. Amer. Proc., 44, 969-74.

Lim, C. H., Jackson, M. L.. Koons, R. D. \& Helmke, P. A. (1980). Kaolins: sources of differences in cation-exchange capacities and cesium retention. Clays Clay Miner., 28, 223-9.

Mann, S. S. (1989). Cadmium in fertilizers and soils. PhD Prelim., University of Western Australia.

Mann, S. S. (1993). Forms of cadmium in soils of Western Australia. PhD Thesis, The University of Western Australia.

Mann, S. S. \& Ritchie, G. S. P. (1993). The effect of pH on the forms of cadmium. Aust. J. Soil Res., 31, 255-70.

Neal, R. H. \& Sposito, G. (1986). Effects of soluble organic matter and sewage sludge amendments on Cd sorption by soils at low Cd concentrations. Soil Sci., 142, 16472.

Northcote, K. H. (1974). A Factual Key for the Recognition of Australian Soils, 3rd edn. Rellim Technical Publications, Glenside, South Australia.

Ozanne, P. G. \& Shaw, T. C. (1967). Phosphate sorption by soils as a measure of the phosphate requirement for pasture growth. Aust. J. Agric. Res., 18, 601-12.

Soon, Y. K. \& Bates, T. E. (1982). Chemical pools of Cd, Ni and $\mathrm{Zn}$ in polluted soils and some preliminary indications of their availability to plants. $J$. Soil Sci., 33, 477-88.

Sposito, G. \& Page, A. L. (1985). Circulation of metals in the environment. In Metal lons in Biological Systems, ed. $\mathrm{H}$. Sigel. Marcel Dekker, New York, pp. 359-66.

Tacey, W. H., Ward, S. C. \& Summers, K. J. (1984). Soil improvement with bauxite residue. J. Agric. West. Aust., 25, 92-3.

Tiller, K. G. (1988). Cadmium accumulation in the soil-plant system: an overview in relation to possible transfers to agricultural products. In Cadmium Accumulations in Australian Agriculture, ed. J. Simpson \& B. Curnow. Australian Government Publishing Service, Canberra, No. 2, pp. 2047.

Tyler, L. D. \& McBride, M. B. (1982). Mobility and extractability of cadmium, copper, nickel and zinc in organic and mineral soil columns. Soil Sci., 134, 198-205.

Van Riemsdijk, W. H., De Wit, J. C. M., Nederlof, M. M. \& Koopal, L. K. (1990). Physico-chemical models for metal ion behaviour in soil. In Contaminated Soil ' 90 ', Vol. I, ed F. Arendt, M. Hinsenveld \& V. Brink. Kluwer Academic Publishers, Karlsruhe, pp. 359-66.

Verloo, M. \& Willaert, G. (1990). Direct and indirect effects of fertilization practices on heavy metals in plants and soil. In Fertilization and the Environment, ed. R. Merckx, H. Vereecken \& K. Vlassak. Leuven University Press, Leuven, pp. 79-87.

Vlahos, S., Summers, K. J., Bell, D. T. \& Gilkes, R. J. (1989). Reducing phosphorus leaching from sandy soils with red mud bauxite processing residues. Aust. J. Soil Res., 27, 651-62.

Weaver, D. M., Ritchie, G. S. P., Anderson, G. C. \& Deeley, D. M. (1988). Phosphorus leaching in sandy soils: I Shortterm effects of fertilizer applications and environmental conditions. Aust. J. Soil Res., 26, 177-90.

Williams, C. H. \& David, D. J. (1973). The effect of superphosphate on the cadmium content of soils and plants. Aust. J. Soil Res., 11, 43-56. 